\title{
AN INTERPRETATION OF NEW ZEALAND'S REGIONAL EMPLOYMENT CHANGE BY MEANS OF CLASSIC SHIFT-SHARE ANALYSIS 1986-2001 ${ }^{1}$
}

\author{
Sandra Baxendine \\ Bill Cochrane \\ Ian Pool \\ Jacques Poot \\ Population Studies Centre \\ University of Waikato
}

\begin{abstract}
Over the last two decades New Zealand has undergone fundamental economic restructuring, and phases of slow and rapid growth, which have resulted in some dramatic changes in the regional economies. This paper focuses on changes in regional employment outcomes in terms of the impact of national trends on regions, sectoral composition within regions, structural change and local conditions. These changes are quantified by means of classic shift-share analysis. Regions are clustered based on the direction and relative importance of national and region-specific effects. The clustering highlights the chasm that has developed in New Zealand between metropolitan and other services-oriented regions vis-á-vis rural and peripheral regions.
\end{abstract}

\section{Introduction}

Many countries are witnessing growing diversity among sub-national regions. New Zealand is no exception. Traditionally, differences between New Zealand regions in economic conditions and the standard of living were rather small. A protected domestic economy with centralised wage bargaining and uniform prices, combined with export revenues generated by a narrow range of agricultural outputs produced in many parts of the country, led to a rather egalitarian society both interpersonally and spatially. In this context, regionallyspecific policies were considered rather unnecessary.

This situation changed when a major recession in 1967 (triggered by a sharp decline in the terms of trade) affected some regions more than others and provided the impetus for an assessment of the need for regional policies. This assessment nonetheless advocated a rather "hands-off" approach (McDonald, 1969). Since then, the policy debate has gone through several cycles of greater or lesser emphasis on regionally-oriented measures (see Karagedikli et al. 2000 and Killerby et al. 2004 for overviews).

Two decades of economic reforms and globalisation forces have contributed to a widening of the income distribution, both across people and across regions (see, e.g., Karagedikli et al. 2002). Also more broadly we are witnessing growing diversity across New Zealand regions in terms of demographic, economic and social features (Pool et al, forthcoming). The need for a better understanding of what drives differences in regional outcomes is therefore greater than ever.

One classic hypothesis is that regional wellbeing is a function of a region's 'endowment' of industries. Deviation of regional growth from national growth can then be explained by the presence of industries in the region that have been growing above or below average nationwide. This hypothesis has led to a popular decomposition of regional employment growth into a national growth effect, an industry mix effect and a residual. The latter is often labelled the competitive or differential effect.

This decomposition is referred to in the literature as shiftshare analysis, which has been a popular descriptive tool of regional analysis since the 1960 s (see, e.g. Loveridge and Selting 1998, Dinc et al. 1998, and Knudsen 2000 for surveys).

Despite its enduring popularity, shift-share analysis has also attracted severe criticism over the years. The weaknesses of this technique include sensitivity to the level of aggregation and the omission of the impact of intra-regional inter-industry linkages. It is clear that shiftshare analysis by itself is simply an accounting procedure and does not constitute a model of the regional economy. However, the decomposition of regional employment growth into a national growth effect, an industry mix effect and a residual effect can be a useful stepping stone for the further analysis of causes of regional growth differentials. This is the approach adopted in the present paper.

Shift-share analysis has had little application in New Zealand, with Patterson's (1989) study of regional employment change 1981-86 being one of the few exceptions. In this paper we present the results of a classic shift-share analysis of employment growth in 29 New Zealand regions over three periods: 1986-1991, 1991-1996 and 1996-2001. The relative importance to a region of its industry mix effect in explaining regional employment growth differentials turns out to be rather 
stable over time. There is less stability in the relative importance of the competitive effect. Grouping regions in terms of the magnitude and direction of the industry mix and competitive effects generates a two-way classification that is useful for identifying clusters of regions. These clusters are described here. We also comment briefly on our work on some alternative approaches to shift-share analysis, introduced to overcome some of the weaknesses of the classic method. These results are reported in a separate paper. However, we find that these refinements add little to our understanding of the role of the industry mix effect vis-àvis the competitive shift effect in regional growth.

\section{Classic Multi-Period Shift-Share Analysis}

In a small open economy such as New Zealand, the demand for output in many sectors in any particular region is a function of national economic conditions and international influences. Thus, it is plausible that regions do well when they are 'endowed' with industries that are experiencing a growth in demand nationwide, for example due to favourable terms of trade or booming demand overseas. Shift-share analysis is a simple tool to quantify the importance of this endowment effect. Of course, by carrying out the analysis for successive periods, the change in the regional 'endowment' of industries is taken into account. In addition, we will explicitly quantify the impact of a change in industry shares on the industry mix effect in each region.

The importance of industry composition for the regional business cycles in New Zealand was recently confirmed by Hall and McDermott (2004). Using various statistical methods, Hall and McDermott identified meaningful regional business cycles and found that relatively rural (i.e. primary sector driven) regions are strongly influenced by external economic shocks such as the terms of trade and the real price of milk solids. Thus, with external influences playing a major role in the relative fortunes of New Zealand industries, the "endowment effect' of industry composition in regions is likely to be rather important. Shift-share analysis that quantifies the industry mix effect provides therefore useful insight into regional employment growth.

However, before describing the calculations and the results, it is useful to elaborate on the limitations of the methodology (see also, e.g. Mulligan and Molin, 2004). First, the results are sensitive to the extent of disaggregation. The more disaggregated the regional data, the more important the industry mix effect is relative to the competitive effect. But, since our objective is to identify and rank relatively regional fortunes rather than assess the absolute contribution of the industry mix effect, this is not a major issue in this paper.

Interpretation problems also arise when the regions are of very different population sizes. In the present application, this is avoided by breaking employment in metropolitan regions into constituent parts. Another common issue is the choice of the reference region, which can be the nation, but alternatively can also be some other benchmark. Since our analysis disaggregates total New Zealand employment into 29 regions, with even the largest (Auckland city) accounting for no more than 10 percent of employment, the nation is the natural benchmark.

Caution is also needed with the interpretation of the competitive effect as indicative of the average degree of competitiveness of all industries in the region. The competitive effect is simply calculated as a residual. A region can have a negative competitive effect when most of its industries are highly efficient and have experienced rapid employment growth, but a few large industries in the region are in decline.

Another weakness of shift-share analysis is that it does not take intra-regional inter-industry linkages into account. For example, regional employment growth in an export sector (say, the dairy sector) is likely to spill over to the manufacturing sectors in that region even though manufacturing employment overall may have been in decline. The growth of manufacturing employment in that region is then quantified in the region's competitive component of overall employment change, but it would be wrong to interpret this as evidence of growing competitiveness of the manufacturing sector in that region. There is unfortunately no information available on regional input-output transactions in New Zealand, although there certainly is a demand for this type of information and a regional input-output table may be developed in the future (Statistics New Zealand 2003). Regional impact studies use multipliers derived by indirect methods such as described by Butcher (1985). Without input-output information, the extent of crossindustry intra-regional spillovers cannot be quantified. However, the most important weakness of the shift-share methodology is that it says nothing about efficiency and productivity. In certain regions, rapid employment growth may be due to expansion of public services funded by central government. If such expansionary regional policy targets specific regions, shift-share analysis will suggest a large competitive growth component in those regions. This is, however, unlikely to be sustainable growth, as the employment is funded with income generated outside the region. Similarly, a boom in new dwelling construction or major infrastructure projects (e.g. motorway construction) in some regions may generate significant employment growth, but again of an unsustainable nature. Ideally, regional growth should disentangle capital productivity growth, labour productivity growth and total factor productivity growth (e.g., Haynes and Dinc, 1997). This line of research would require information on regional sectoral outputs and capital stocks, besides regional employment levels. The absence of such data makes productivity analysis at the regional level infeasible in New Zealand.

Despite these weaknesses, shift-share analysis remains a popular tool for regional economic analysis simply because the data demands are few and the basic idea of accounting for composition effects is as powerful as that of age standardisation in demography. As many authors (such as Dinc et al. 1998) have noted, the classic shiftshare model and it extensions remain a useful descriptive 
technique that can provide various kinds of information about the regional economy. The classic shift-share decomposition is presented in Table 1.

The data for this analysis were obtained from the quinquennial New Zealand Census of Population and Dwellings 1986 to 2001. Unpublished information was obtained on employment by age (15-24, 25-44, 45-64), sex, employment status (full-time and part-time), industry (7 categories), occupation ( 7 categories) and region (29 areas). Not specified responses are excluded. The extent of disaggregation is fairly limited, but was dictated by maintaining intercensal comparability. For example, due to difficulties in consistently defining ethnicity across the four censuses at this level of disaggregation, it was not possible to account for ethnic composition in this analysis. A more detailed discussion of the data and methodology used is to be found in Poot et al. (forthcoming).

Table 2 reports full-time equivalent (FTE) employment growth across the three intercensal periods 1986-91, 1991-96 and 1996-2001. Table 2 reinforces the well known fact that the 1986-91 period of radical economic reform, restructuring and a cyclical downturn at the end of the period coincided with sharp employment declines in most sectors except for business and financial services (29.5 percent growth) and public services, social services and utilities ( 2.0 percent growth). Total FTE employment declined by 9.7 percent. Manufacturing employment declined by 27.1 percent.

Table 1: The Classic Shift-share Decomposition (Dunn, 1960; Ashby, 1968) and a Simple Extension

$E_{i j}^{t}-E_{i j}^{t-1} \equiv \Delta E_{i j}^{t} \equiv N E_{i j}^{t}+I M_{i j}^{t}+C E_{i j}^{t}$,

where

$E_{i j}^{t} \quad$ is Employment in the $i^{\text {th }}$ industry in the $j^{\text {th }}$ region at time $t$,

$N E_{i j}^{t}$ is the National Growth Effect on industry $i$ in the $j^{\text {th }}$ region between times $(t-1)$ and $t$,

$I M_{i j}^{\prime}$ is the Industry Mix Effect on industry $i$ in the $f^{\text {th }}$ region between times $(t-1)$ and $t$,

$C E_{i j}^{t}$ is the Competitive Effect on industry $i$ in the $j^{t h}$ region between times $(t-1)$ and $t$.

The three effects are computed as follows:

$N E_{i j}^{t}=g_{00}^{t} \times E_{i j}^{t-1}$,
$I M_{i j}^{t}=\left(g_{i 0}^{t}-g_{00}^{t}\right) \times E_{i j}^{t-1}$,
$C E_{i j}^{t}=\left(g_{i j}^{t}-g_{i 0}^{t}\right) \times E_{i j}^{t-1}$,

where

$g_{i j}^{t}$ is the growth rate of employment in industry $i$ and region $j$ between times $(t-1)$ and $t$,

$g_{i 0}^{t}$ is the growth rate of nationwide employment in industry $i$ between times $(t-1)$ and $t$

$g_{00}^{\prime}$ is the growth rate in nationwide total employment between times $(t-1)$ and $t$.

The competitive growth rate of the region $j$ at time $t$ can then be expressed mathematically as:

$r_{j}^{\prime} \equiv g_{0 j}^{\prime}-g_{00}^{t}-\sum_{i} w_{i j}^{t-1}\left(g_{i 0}^{\prime}-g_{00}^{\prime}\right)$

where

$g_{0 j}^{\prime}$ is the growth rate of total employment in region $j$ between times $(t-1)$ and $t$,

$w_{i j}^{t-1}$ is the fraction of employment in region $\mathrm{j}$ that is in industry $i$ at time $(t-1)$

\section{A simple extension}

The industry mix effect, the last RHS term in equation (5), can be decomposed in the following way,

$$
\sum_{i} w_{i j}^{t-1}\left(g_{i 0}^{t}-g_{00}^{t}\right) \equiv \sum_{i} w_{i j}^{t}\left(g_{i 0}^{t}-g_{00}^{t}\right)+\sum_{i}\left(w_{i j}^{t-1}-w_{i j}^{t}\right)\left(g_{i 0}^{\prime}-g_{00}^{\prime}\right)
$$

The term on the most right now measures the effect of changing industry composition on the regional employment growth rate.

We call this the structural change effect and to the industry-mix effect calculated by means of period weights as the modified industry-mix effect. 
Table 2: Full-time Equivalent Employment, 1986-2001

\begin{tabular}{|l|r|r|r|r|}
\hline & FTE 86 & 86-91 & 91-96 & 96-01 \\
\hline $\begin{array}{l}\text { Business and } \\
\text { Financial Services }\end{array}$ & 113,779 & 29.5 & 16.8 & 14.8 \\
\hline $\begin{array}{l}\text { Public Services, } \\
\text { Social Services, } \\
\text { Utilities }\end{array}$ & 290,155 & 2.0 & 2.5 & 14.7 \\
\hline $\begin{array}{l}\text { Personal, } \\
\text { Household, } \\
\text { Restaurants and } \\
\text { Hotels }\end{array}$ & 84,126 & -13.6 & 23.4 & 5.9 \\
\hline $\begin{array}{l}\text { Distribution and } \\
\text { exchange (retail } \\
\text { and wholesale) }\end{array}$ & 312,808 & -12.2 & 7.1 & 7.9 \\
\hline $\begin{array}{l}\text { Building and } \\
\text { Construction }\end{array}$ & 97.255 & -18.8 & 10.0 & 10.9 \\
\hline $\begin{array}{l}\text { Manufacturing } \\
\text { Primary }\end{array}$ & 297.716 & -27.1 & -0.8 & -3.1 \\
\hline $\begin{array}{l}\text { Total FTE } \\
\text { Employment }\end{array}$ & $1,348,729$ & -9.7 & 6.6 & 7.5 \\
\hline
\end{tabular}

The 1991-96 period saw a recovery with employment growth in most sectors, except for manufacturing which continued to contract 0.8 percent. Although some commentators interpreted this period as providing clear evidence of the payoff of economic liberalisation and reforms (e.g. Evans et al. 1996), overall FTE employment growth (6.6 percent) remained insufficient to return to 1986 levels. It is now commonly, but not universally, accepted that a higher sustainable growth path nationwide emerged after 1996 and overall FTE employment growth was 7.5 percent during the 1996-0I period, although there were further declines in manufacturing and primary sector FTE employment.

FTE employment in 1986 and growth over the three subsequent intercensal periods in each region is reported in Table 3. Several regional council regions have been split into several constituent parts as it is expected that they have rather different features. Thus, Auckland is split into North Shore, Auckland City, West Auckland and South Auckland. Waikato consists of North Waikato, Hamilton/Waipa and South Waikato. However, while Rotorua is in the Bay of Plenty regional council and Taupo is in the Waikato regional council, Rotorua and Taupo have here been combined into one separate region. The Western Bay of Plenty is also distinct from the Eastern Bay of Plenty. The Wellington Regional Council Region is divided into Kapiti/Porirua, Hutt Valley, Wellington City and Wairarapa. Manawatu-Wanganui is one regional council region that has been split into Manawatu and Wanganui. In the South Island, Canterbury is divided into Rural Canterbury, South Canterbury and Christchurch City. Finally Otago is split into Dunedin City and Rural Otago. The largest resulting region Auckland City accounts with FTE employment of 127.304 for 9.4 pereent of the New Zealand total in 1986 , while the smallest region in terms of FTE employment at
Table 3: Regional Full-time Equivalent Employment, 1986-2001

\begin{tabular}{|c|c|c|c|c|}
\hline \multirow{2}{*}{ Region } & \multirow{2}{*}{$\begin{array}{l}\text { FTE } \\
1986\end{array}$} & \multicolumn{3}{|c|}{ Percentage Growth } \\
\hline & & $86-91$ & $91-96$ & 96-01 \\
\hline Northland & 47,226 & -19.8 & 5.4 & 7.4 \\
\hline North Shore & 77,929 & -0.6 & 12.0 & 9.2 \\
\hline West Auckland & 61,423 & -3.0 & 11.5 & 11.7 \\
\hline Auckland City & 127,304 & -10.1 & 11.4 & 12.4 \\
\hline South Auckland & 111,465 & -8.0 & 9.4 & 11.3 \\
\hline North Waikato & 31,843 & -8.3 & 4.8 & 8.6 \\
\hline Hamilton/Waipa & 53,894 & -7.1 & 8.1 & 8.7 \\
\hline South Waikato & 31,894 & -15.6 & -5.1 & 0.7 \\
\hline Taupo/Rotorua & 35,348 & -14.8 & 7.8 & 3.8 \\
\hline Western BoP & 33,151 & -5.0 & 17.2 & 18.9 \\
\hline Eastern BoP & 17,059 & -18.7 & -0.4 & 4.4 \\
\hline Gisborne & 17,435 & -22.5 & 0.2 & 3.5 \\
\hline Hawke's Bay & 54,261 & -12.9 & 4.1 & 4.3 \\
\hline Taranaki & 43,751 & -14.6 & -0.8 & -0.9 \\
\hline Wanganui & 31,177 & -18.2 & -2.6 & -1.9 \\
\hline Manawatu & 56,080 & -8.2 & 2.5 & 1.2 \\
\hline Kapiti/Porirua & 28,490 & -5.7 & -1.3 & 15.3 \\
\hline Hutt Valley & 58,312 & -11.8 & -2.7 & 3.5 \\
\hline Wellington City & 74,166 & -8.2 & 3.5 & 8.0 \\
\hline Wairarapa & 14,460 & -12.4 & -0.1 & 9.2 \\
\hline Nelson-Tasman & 27,887 & -5.7 & 12.5 & 7.3 \\
\hline Marlborough & 13,020 & -2.0 & 13.2 & 9.1 \\
\hline West Coast & 13,223 & -17.8 & 1.5 & 0.0 \\
\hline Christchurch City & 114,707 & -9.2 & 9.4 & 6.2 \\
\hline Rural Canterbury & 36,572 & -1.7 & 12.1 & 14.8 \\
\hline South Canterbury & 21,272 & -14.6 & 5.5 & 2.3 \\
\hline Dunedin City & 44,226 & -12.9 & 3.6 & 2.3 \\
\hline Rural Otago & 27,243 & -9.7 & 11.0 & 5.3 \\
\hline Southland & 43,053 & -12.8 & 1.0 & -3.4 \\
\hline NEW ZEALAND & $1,347,869$ & -9.7 & 6.6 & 7.5 \\
\hline
\end{tabular}

that time can be found in Marlborough District (13,020 or just under I percent of the total).

Table 4 reports the components of regional growth, as calculated by classic shift-share analysis. The regions are ranked from the one with the fasted average growth rate (Western Bay of Plenty, 10.4 percent) to the one with the greatest employment decline (Wanganui, -7.6 percent). The first point to note is that in virtually all regions the national growth component is large relative to the industry $\operatorname{mix}$ and competitive components. This reinforces that no New Zealand region was sheltered from the massive employment changes that have taken place since 1986, particularly in the first decade. 
Table 4: Classic Shift-share Decomposition of FTE Employment Growth

\begin{tabular}{|c|c|c|c|c|c|c|c|c|c|c|c|c|}
\hline \multirow[b]{2}{*}{ Region } & \multicolumn{4}{|c|}{ 1986-91 } & \multicolumn{4}{|c|}{$1991-96$} & \multicolumn{4}{|c|}{ 1996-01 } \\
\hline & $\mathbf{\Delta E}$ & NE & IM & CE & $\Delta \mathbf{E}$ & NE & IM & CE & $\Delta \mathbf{E}$ & NE & IM & CE \\
\hline Western Bay of Plenty & -5.0 & -9.7 & -0.7 & 5.4 & 17.2 & 6.6 & 0.0 & 10.5 & 18.9 & 7.5 & -0.7 & 12.1 \\
\hline Rural Canterbury & -1.7 & -9.7 & -1.9 & 9.9 & 12.1 & 6.6 & -0.9 & 6.3 & 14.8 & 7.5 & -2.3 & 9.6 \\
\hline North Shore & -0.6 & -9.7 & 2.6 & 6.6 & 12.0 & 6.6 & 1.1 & 4.4 & 9.2 & 7.5 & 1.5 & 0.2 \\
\hline Marlborough & -2.0 & -9.7 & -0.2 & 7.9 & 13.2 & 6.6 & -0.7 & 7.3 & 9.1 & 7.5 & -1.6 & 3.3 \\
\hline West Auckland & -3.0 & -9.7 & -1.3 & 8.1 & 11.5 & 6.6 & 0.1 & 4.8 & 11.7 & 7.5 & 0.4 & 3.8 \\
\hline Nelson-Tasman & -5.7 & -9.7 & -1.0 & 5.0 & 12.5 & 6.6 & -0.5 & 6.3 & 7.3 & 7.5 & -1.9 & 1.8 \\
\hline Auckland City & -10.1 & -9.7 & 1.4 & -1.8 & 11.4 & 6.6 & 1.1 & 3.7 & 12.4 & 7.5 & 1.7 & 3.3 \\
\hline South Auckland & -8.0 & -9.7 & -3.0 & 4.7 & 9.4 & 6.6 & -0.5 & 3.3 & 11.3 & 7.5 & -0.5 & 4.3 \\
\hline Hamilton/Waipa & -7.1 & -9.7 & 1.6 & 1.0 & 8.1 & 6.6 & 0.0 & 1.5 & 8.7 & 7.5 & 0.8 & 0.5 \\
\hline Kapiti/Porirua & -5.7 & -9.7 & 2.4 & 1.7 & -1.3 & 6.6 & 0.6 & -8.4 & 15.3 & 7.5 & 1.9 & 6.0 \\
\hline Rural Otago & -9.7 & -9.7 & -2.3 & 2.4 & 11.0 & 6.6 & -0.1 & 4.5 & 5.3 & 7.5 & -2.4 & 0.2 \\
\hline Christchurch City & -9.2 & -9.7 & 0.0 & 0.6 & 9.4 & 6.6 & 0.1 & 2.7 & 6.2 & 7.5 & 0.6 & -1.8 \\
\hline North Waikato & -8.3 & -9.7 & -2.2 & 3.7 & 4.8 & 6.6 & -0.8 & -1.0 & 8.6 & 7.5 & -2.4 & 3.5 \\
\hline Wellington City & -8.2 & -9.7 & 7.8 & -6.2 & 3.5 & 6.6 & 1.9 & -5.0 & 8.0 & 7.5 & 3.9 & -3.3 \\
\hline Taupo/Rotorua & -14.8 & -9.7 & -0.3 & -4.8 & 7.8 & 6.6 & 0.6 & 0.6 & 3.8 & 7.5 & -0.2 & -3.4 \\
\hline Wairarapa & -12.4 & -9.7 & -1.6 & -1.0 & -0.1 & 6.6 & -0.5 & -6.2 & 9.2 & 7.5 & -1.6 & 3.4 \\
\hline Manawatu & -8.2 & -9.7 & -0.3 & 1.9 & 2.5 & 6.6 & -0.9 & -3.3 & 1.2 & 7.5 & -0.4 & -5.9 \\
\hline Hawke's Bay & -12.9 & -9.7 & -1.9 & -1.3 & 4.1 & 6.6 & -0.9 & -1.6 & 4.3 & 7.5 & -1.6 & -1.6 \\
\hline South Canterbury & -14.6 & -9.7 & -1.7 & -3.1 & 5.5 & 6.6 & -0.9 & -0.2 & 2.3 & 7.5 & -2.3 & -2.8 \\
\hline Northland & -19.8 & -9.7 & -1.5 & -8.6 & 5.4 & 6.6 & -0.3 & -0.9 & 7.4 & 7.5 & -1.4 & 1.3 \\
\hline Dunedin City & -12.9 & -9.7 & 1.3 & -4.5 & 3.6 & 6.6 & 0.0 & -3.0 & 2.3 & 7.5 & 1.3 & -6.4 \\
\hline Hutt Valley & -11.8 & -9.7 & 1.8 & -3.8 & -2.7 & 6.6 & 0.5 & -9.9 & 3.5 & 7.5 & 1.8 & -5.7 \\
\hline Eastern Bay of Plenty & -18.7 & -9.7 & -3.7 & -5.3 & -0.4 & 6.6 & -1.2 & -5.8 & 4.4 & 7.5 & -2.1 & -1.0 \\
\hline Southland & -12.8 & -9.7 & -1.8 & -1.2 & 1.0 & 6.6 & -1.1 & -4.5 & -3.4 & 7.5 & -2.5 & -8.3 \\
\hline West Coast & -17.8 & -9.7 & -1.6 & -6.5 & 1.5 & 6.6 & -0.2 & -4.9 & 0.0 & 7.5 & -1.7 & -5.8 \\
\hline Taranaki & -14.6 & -9.7 & -1.5 & -3.4 & -0.8 & 6.6 & -0.9 & -6.5 & -0.9 & 7.5 & -1.8 & -6.6 \\
\hline Gisborne & -22.5 & -9.7 & -0.6 & -12.1 & 0.2 & 6.6 & -0.8 & -5.6 & 3.5 & 7.5 & -1.3 & -2.7 \\
\hline South Waikato & -15.6 & -9.7 & -3.5 & -2.3 & -5.1 & 6.6 & -1.4 & -10.2 & 0.7 & 7.5 & -3.9 & -2.9 \\
\hline Wanganui & -18.2 & -9.7 & 0.1 & -8.6 & -2.6 & 6.6 & -0.9 & -8.4 & -1.9 & 7.5 & -0.5 & -8.9 \\
\hline
\end{tabular}

The industry mix effect is in many regions small relative to the competitive effect. But, as noted earlier, this is partially a function of the level of industrial disaggregation, so we cannot read too much into this. It is more useful to rank regions based on the average industry mix effect over the 1986-2001 period. The results are shown in Table 5.

The solid lines in Table 5 separate the regions into those with an industry mix effect of more than 1 percent, between -1 and +1 percent, and less than -1 percent on average. However, the ranking is quite stable over time. The regions where the industry composition has been particularly favourable for employment growth are all in Auckland or Wellington metropolitan areas. Karagedikli et al. (2000) identified a dichotomy in New Zealand of relatively fast economic growth in Auckland and Wellington, vis-à-vis the rest of New Zealand and Table 5 suggests that a favourable employment structure (with a disproportionally large share of business and financial services) is one factor responsible for this outcome. Industry mix has been particularly disadvantageous for Eastern Bay of Plenty and South Waikato. The stability in the rankings of the industry mix effects suggests that an advantageous or disadvantageous sector structure can only change very gradually. It also suggests that the only protection to sector-specific employment shocks is sectoral diversification, analogous to portfolio diversification in finance (see also, for example, Munro and Schachter 2000 on this issue in the European Union). 
Table 5: Regions Ranked in Terms of the Industry Mix Effect

\begin{tabular}{|c|c|c|c|c|c|c|c|c|}
\hline \multirow{2}{*}{ Region } & \multicolumn{2}{|c|}{$1986-91$} & \multicolumn{2}{|c|}{ 1991-96 } & \multicolumn{2}{|c|}{ 1996-01 } & \multicolumn{2}{|c|}{ Average } \\
\hline & $\%$ & Rank & $\%$ & Rank & $\%$ & Rank & $\%$ & Rank \\
\hline Wellington City & 7.8 & 1 & 1.9 & 1 & 3.9 & 1 & 4.5 & 1 \\
\hline North Shore & 2.6 & 2 & 1.1 & 3 & 1.5 & 5 & 1.7 & 2 \\
\hline Kapiti/Porirua & 2.4 & 3 & 0.6 & 5 & 1.9 & 2 & 1.6 & 3 \\
\hline Auckland City & 1.4 & 6 & 1.1 & 2 & 1.7 & 4 & 1.4 & 4 \\
\hline Hutt Valley & 1.8 & 4 & 0.5 & 6 & 1.8 & 3 & 1.4 & 5 \\
\hline Dunedin City & 1.3 & 7 & 0.0 & 11 & 1.3 & 6 & 0.8 & 6 \\
\hline Hamilton/Waipa & 1.6 & 5 & 0.0 & 10 & 0.8 & 7 & 0.8 & 7 \\
\hline Christchurch City & 0.0 & 9 & 0.1 & 7 & 0.6 & 8 & 0.2 & 8 \\
\hline Taupo/Rotorua & -0.3 & 11 & 0.6 & 4 & -0.2 & 10 & 0.0 & 9 \\
\hline West Auckland & -1.3 & 16 & 0.1 & 8 & 0.4 & 9 & -0.3 & 10 \\
\hline Wanganui & 0.1 & 8 & -0.9 & 21 & -0.5 & 12 & -0.4 & 11 \\
\hline Western Bay of Plenty & -0.7 & 14 & 0.0 & 9 & -0.7 & 14 & -0.4 & 12 \\
\hline Manawatu & -0.3 & 12 & -0.9 & 22 & -0.4 & 11 & -0.5 & 13 \\
\hline Marlborough & -0.2 & 10 & -0.7 & 18 & -1.6 & 19 & -0.9 & 14 \\
\hline Gisborne & -0.6 & 13 & -0.8 & 20 & -1.3 & 15 & -0.9 & 15 \\
\hline Northland & -1.5 & 17 & -0.3 & 14 & -1.4 & 16 & -1.0 & 16 \\
\hline Nelson-Tasman & -1.0 & 15 & -0.5 & 15 & -1.9 & 22 & -1.1 & 17 \\
\hline West Coast & -1.6 & 19 & -0.2 & 13 & -1.7 & 20 & -1.2 & 18 \\
\hline Wairarapa & -1.6 & 20 & -0.5 & 17 & -1.6 & 17 & -1.2 & 19 \\
\hline South Auckland & -3.0 & 27 & -0.5 & 16 & -0.5 & 13 & -1.3 & 20 \\
\hline Taranaki & -1.5 & 18 & -0.9 & 25 & -1.8 & 21 & -1.4 & 21 \\
\hline Hawke's Bay & -1.9 & 24 & -0.9 & 26 & -1.6 & 18 & -1.5 & 22 \\
\hline Rural Otago & -2.3 & 26 & -0.1 & 12 & -2.4 & 27 & -1.6 & 23 \\
\hline South Canterbury & -1.7 & 21 & -0.9 & 24 & -2.3 & 24 & -1.6 & 24 \\
\hline Rural Canterbury & -1.9 & 23 & -0.9 & 23 & -2.3 & 25 & -1.7 & 25 \\
\hline North Waikato & -2.2 & 25 & -0.8 & 19 & -2.4 & 26 & -1.8 & 26 \\
\hline Southland & -1.8 & 22 & -1.1 & 27 & -2.5 & 28 & -1.8 & 27 \\
\hline Eastern Bay of Plenty & -3.7 & 29 & -1.2 & 28 & -2.1 & 23 & -2.3 & 28 \\
\hline South Waikato & -3.5 & 28 & -1.4 & 29 & -3.9 & 29 & -2.9 & 29 \\
\hline
\end{tabular}

Equation (5) in Table 1 above shows that the industry mix effect is calculated by means of industry shares at the beginning of the intercensal period. The question then arises to what extent over the intercensal period the regional shares adjust such that employment increases in sectors that are nationally doing well or whether some regions in fact "go against the trend" and increase the share of industries that are nationally contracting. This can be investigated by means of the decomposition shown in equation (6), Table 1. The industry mix effect in its modified form, plus the structural change effect are reported for all three intercensal periods in Table 6.
The modified industry mix effect signals the same phenomenon as before. Employment in regions that are primarily urban and service-sector focussed benefited from the growth in services. They include all parts of the greater Auckland region, except South Auckland; all parts of the greater Wellington region, except Wairarapa, Christchurch City, Dunedin City, Hamilton/Waipa and Taupo/Rotorua. In contrast, industry mix has been detrimental to the rural hinterlands of South Waikato, Eastern Bay of Plenty, South Canterbury and Southland. In terms of magnitude, the industry mix effect is in most regions the largest during the 1986-91 period. 
Table 6: The Modified Industry Mix and Structural Change Effects on Growth

\begin{tabular}{|c|c|c|c|c|c|c|c|c|}
\hline \multirow{2}{*}{ Region } & \multicolumn{4}{|c|}{ Modified Industry Mix Effect } & \multicolumn{4}{|c|}{ Structural Change Effect } \\
\hline & $1986-91$ & 1991-96 & 1996-01 & Average & $1986-91$ & $1991-96$ & 1996-01 & Average \\
\hline Northland & 0.9 & -0.1 & -0.7 & 0.1 & -2.4 & -0.2 & -0.7 & -1.1 \\
\hline North Shore & 5.7 & 1.5 & 1.9 & 3.0 & -3.1 & -0.4 & -0.4 & -1.3 \\
\hline West Auckland & 1.9 & 0.5 & 1.0 & 1.1 & -3.1 & -0.4 & -0.6 & -1.4 \\
\hline Auckland City & 5.7 & 1.7 & 2.3 & 3.2 & -4.2 & -0.5 & -0.6 & -1.8 \\
\hline South Auckland & 0.3 & 0.0 & 0.1 & 0.2 & -3.3 & -0.5 & -0.6 & -1.5 \\
\hline North Waikato & -0.6 & -0.3 & -1.5 & -0.8 & -1.6 & -0.4 & -0.9 & -1.0 \\
\hline Hamilton/Waipa & 3.8 & 0.4 & 1.1 & 1.8 & -2.2 & -0.4 & -0.4 & -1.0 \\
\hline South Waikato & -2.3 & -1.1 & -3.4 & -2.3 & -1.2 & -0.3 & -0.5 & -0.7 \\
\hline Taupo/Rotorua & 2.3 & 0.9 & 0.1 & 1.1 & -2.6 & -0.3 & -0.4 & -1.1 \\
\hline Western Bay of Plenty & 1.0 & 0.4 & -0.1 & 0.4 & -1.7 & -0.4 & -0.6 & -0.9 \\
\hline Eastern Bay of Plenty & -1.3 & -0.9 & -1.5 & -1.2 & -2.4 & -0.3 & -0.6 & -1.1 \\
\hline Gisborne & 1.0 & -0.4 & -1.2 & -0.2 & -1.7 & -0.4 & -0.1 & -0.7 \\
\hline Hawke's Bay & 0.2 & -0.6 & -1.3 & -0.6 & -2.0 & -0.4 & -0.3 & -0.9 \\
\hline Taranaki & -0.1 & -0.5 & -1.4 & -0.7 & -1.4 & -0.4 & -0.4 & -0.7 \\
\hline Wanganui & 1.6 & -0.5 & -0.5 & 0.2 & -1.6 & -0.4 & 0.0 & -0.6 \\
\hline Manawatu & 1.5 & -0.5 & 0.1 & 0.4 & -1.8 & -0.3 & -0.5 & -0.9 \\
\hline Kapiti/Porirua & 5.4 & 0.9 & 2.5 & 2.9 & -3.0 & -0.3 & -0.5 & -1.3 \\
\hline Hutt Valley & 5.6 & 0.8 & 2.3 & 2.9 & -3.8 & -0.3 & -0.5 & -1.5 \\
\hline Wellington City & 11.4 & 2.3 & 4.1 & 5.9 & -3.6 & -0.4 & -0.2 & -1.4 \\
\hline Wairarapa & 1.3 & -0.4 & -1.1 & 0.0 & -3.0 & -0.1 & -0.5 & -1.2 \\
\hline Nelson-Tasman & 0.5 & -0.1 & -1.2 & -0.3 & -1.5 & -0.4 & -0.7 & -0.8 \\
\hline Marlborough & 0.1 & -0.4 & -1.8 & -0.7 & -0.3 & -0.3 & 0.2 & -0.2 \\
\hline West Coast & 0.3 & 0.3 & -1.3 & -0.2 & -1.9 & -0.5 & -0.4 & -0.9 \\
\hline Christchurch City & 2.9 & 0.5 & 1.0 & 1.5 & -2.9 & -0.3 & -0.4 & -1.2 \\
\hline Rural Canterbury & -0.4 & -0.4 & -1.7 & -0.9 & -1.5 & -0.5 & -0.6 & -0.8 \\
\hline Dunedin City & 4.0 & 0.4 & 1.5 & 2.0 & -2.7 & -0.4 & -0.2 & -1.1 \\
\hline Rural Otago & -1.0 & 0.6 & -2.1 & -0.8 & -1.3 & -0.7 & -0.3 & -0.8 \\
\hline South Canterbury & -0.7 & -0.6 & -2.2 & -1.2 & -1.0 & -0.3 & -0.1 & -0.5 \\
\hline Southland & -1.2 & -0.6 & -2.4 & -1.4 & -0.6 & -0.5 & -0.1 & -0.4 \\
\hline
\end{tabular}

The structural effect is negative in almost all cases. The only exceptions are Wanganui and Marlborough during 1996-2001. The negative sign indicates that regions have generally not gone against the national trend in terms of structural change. If a sector grows faster (slower) than average nationally, its share in employment increases (decreases) in almost all regions. In addition, it is very clear from the magnitudes of the structural effects that the extent of structural employment change was the largest during the first intercensal period. This period coincided with initial phase of the post-1984 economic reforms during which international trade and financial services were liberalised and industry subsidies abolished (with labour market and social security reform following in 1991).

Turning now to the competitive growth rate calculated by equation (5), the results are reported in Table 7. Regions have been ranked by the average competitive effect over the three periods. The solid lines in Table 7 separate the regions into those with an competitive effect of more than 1 percent, between -1 and +1 percent, and less than -1 percent on average.

With respect to Table 7, the first point to note is that there is less stability in the ranking according to the competitive effect than according to the industry mix effect. The relative persistence is quantified in Table 8 , which compares Spearman's rank correlation coefficients for regional growth rates, the industry mix growth rates and the competitive growth rates across pairs of intercensal periods. The highest rank correlation coefficients are found for the industry mix growth rates, which reinforces an earlier point on relatively gradual change across regions in industrial composition. The lowest rank correlation is found for the competitive growth rates, except for comparison of $86 / 91$ with $91 / 96$ where the regional growth rates themselves have the lowest rank correlation (0.652). However, all rank correlations are significant at the 1 percent level, 
illustrating the persistence in the forces of regional employment change. In addition, the lower correlations for the competitive and overall growth effects vis-à-vis the industry mix effect suggest that specific economic changes matter more than the national trends. However, it should be recalled that the competitive effect is simply residual growth after national growth and industry mix have been taken into account. By its very nature, such residual growth is more variable. Nonetheless, it is clear that employment growth in for example Western Bay of
Plenty, Rural Canterbury and Marlborough has been much more than could have been expected based on national trends and their sectoral composition, while regions such as Gisborne and Wanganui have been doing much worse. Having now decomposed regional employment growth into the industry mix and competitive effects, it is useful to assess the extent to which regions are clustered on the basis of common trends. The next section defines such clusters.

Table 7: Regions Ranked in Terms of the Competitive Effect of Shift-Share Analysis

\begin{tabular}{|c|c|c|c|c|c|c|c|c|}
\hline \multirow{2}{*}{ Region } & \multicolumn{2}{|c|}{$1986-91$} & \multicolumn{2}{|c|}{$1991-96$} & \multicolumn{2}{|c|}{ 1996-01 } & \multicolumn{2}{|c|}{ Average } \\
\hline & $\%$ & Rank & $\%$ & Rank & $\%$ & Rank & $\%$ & Rank \\
\hline Western Bay of Plenty & 5.4 & 5 & 10.5 & 1 & 12.1 & 1 & 9.4 & 1 \\
\hline Rural Canterbury & 9.9 & 1 & 6.3 & 3 & 9.6 & 2 & 8.6 & 2 \\
\hline Marlborough & 7.9 & 3 & 7.3 & 2 & 3.3 & 8 & 6.2 & 3 \\
\hline West Auckland & 8.1 & 2 & 4.8 & 5 & 3.8 & 5 & 5.6 & 4 \\
\hline Nelson-Tasman & 5.0 & 6 & 6.3 & 4 & 1.8 & 10 & 4.4 & 5 \\
\hline South Auckland & 4.7 & 7 & 3.3 & 9 & 4.3 & 4 & 4.1 & 6 \\
\hline North Shore & 6.6 & 4 & 4.4 & 7 & 0.2 & 13 & 3.7 & 7 \\
\hline Rural Otago & 2.4 & 9 & 4.5 & 6 & 0.2 & 14 & 2.4 & 8 \\
\hline North Waikato & 3.7 & 8 & -1.0 & 15 & 3.5 & 6 & 2.0 & 9 \\
\hline Auckland City & -1.8 & 17 & 3.7 & 8 & 3.3 & 9 & 1.7 & 10 \\
\hline Hamilton/Waipa & 1.0 & 12 & 1.5 & 11 & 0.5 & 12 & 1.0 & 11 \\
\hline Christchurch City & 0.6 & 13 & 2.7 & 10 & -1.8 & 17 & 0.5 & 12 \\
\hline Kapiti/Porirua & 1.7 & 11 & -8.4 & 27 & 6.0 & 3 & -0.3 & 13 \\
\hline Wairarapa & -1.0 & 14 & -6.2 & 24 & 3.4 & 7 & -1.3 & 14 \\
\hline Hawke's Bay & -1.3 & 16 & -1.6 & 16 & -1.6 & 16 & -1.5 & 15 \\
\hline South Canterbury & -3.1 & 19 & -0.2 & 13 & -2.8 & 19 & -2.1 & 16 \\
\hline Manawatu & 1.9 & 10 & -3.3 & 18 & -5.9 & 25 & -2.4 & 17 \\
\hline Taupo/Rotorua & -4.8 & 23 & 0.6 & 12 & -3.4 & 22 & -2.5 & 18 \\
\hline Northland & -8.6 & 27 & -0.9 & 14 & 1.3 & 11 & -2.7 & 19 \\
\hline Eastern Bay of Plenty & -5.3 & 24 & -5.8 & 23 & -1.0 & 15 & -4.0 & 20 \\
\hline Dunedin City & -4.5 & 22 & -3.0 & 17 & -6.4 & 26 & -4.6 & 21 \\
\hline Southland & -1.2 & 15 & -4.5 & 19 & -8.3 & 28 & -4.7 & 22 \\
\hline Wellington City & -6.2 & 25 & -5.0 & 21 & -3.3 & 21 & -4.8 & 23 \\
\hline South Waikato & -2.3 & 18 & -10.2 & 29 & -2.9 & 20 & -5.1 & 24 \\
\hline Taranaki & -3.4 & 20 & -6.5 & 25 & -6.6 & 27 & -5.5 & 25 \\
\hline West Coast & -6.5 & 26 & -4.9 & 20 & -5.8 & 24 & -5.7 & 26 \\
\hline Hutt Valley & -3.8 & 21 & -9.9 & 28 & -5.7 & 23 & -6.5 & 27 \\
\hline Gisborne & -12.1 & 29 & -5.6 & 22 & -2.7 & 18 & -6.8 & 28 \\
\hline Wanganui & -8.6 & 28 & -8.4 & 26 & -8.9 & 29 & -8.6 & 29 \\
\hline
\end{tabular}

Table 8: Persistence in Regional Employment Growth and its Components

\begin{tabular}{|l|c|c|c|}
\hline Compare Ranking & Regional Growth Rate & Industry Mix Growth Rate & Competitive Growth Rate \\
\hline $86 / 91$ with $91 / 96$ & 0.652 & 0.711 & 0.684 \\
\hline $91 / 96$ with $96 / 01$ & 0.608 & 0.796 & 0.569 \\
\hline $86 / 91$ with $96 / 01$ & 0.706 & 0.863 & 0.665 \\
\hline
\end{tabular}

\section{Regional Clusters}

Given the decomposition of regional FTE employment growth by means of classic shift-share analysis in the previous section, it is useful to assess to what extent there are natural groupings among the regions. For this purpose, we first classify growth effects as positive (1 percent or more), small or negligible (between -1 percent and +1 percent $)$, or negative $(-1$ percent or less). These were the same markers as in Tables 5 and 7 . Combining this division for both the industry mix and competitive effects, yields a three by three matrix, given in Table 9. 
Only two regions have had both positive industry mix and competitive effects on average over the 1986-2001 period. They are North Shore and Auckland City. In a sense, these are one region as employment in the census is recorded at the residential location of the worker and not at the workplace. Many suburban workers on the North Shore of Auckland work in Auckland city. Nonetheless, the result is interesting as it confirms the special role of Auckland in the New Zealand labour market as a traditional growth pole in a national context (Perroux 1950), which has now also extended that role to one of a New Zealand node in a global city system network that links the large-scale urban agglomerations of developed and newly industrialising economies (see e.g. Poot, 2002). In a sense, Auckland is New Zealand's mega-city, in terms of providing a knowledge-driven, innovation-generating and globally connected economy, although with FTE employment around half a million it remains small by international standards. In any case, there is significant heterogeneity within the Auckland region, with West Auckland and South Auckland having positive competitive effects, but small and negative industry mix effects respectively.

Diagonally opposite the Auckland case is that of rural and peripheral regions. This group of regions has three subgroups. The first comprises the North Island regions of Northland, South Waikato, Eastern Bay of Plenty and Hawke's Bay. They have in common a relatively large Maori population of more than 20 per cent of the total. Here disadvantage of region is obviously synonymous with disadvantage of people, with Maori more than proportionally employed in less skilled positions in declining industries. To disentangle the supply (occupation) and demand (industry) effects, a multi-factor shift-share analysis is conducted in Poot et al. (forthcoming).
The second group in the bottom right hand corner of Table 9 consists of Taranaki and Wairarapa, which are peripheral North Island regions. The third group comprises the South Island regions of West Coast, South Canterbury and Southland which are peripheral rural regions without diversified economies. The region which do well in terms of the competitive effect but not so well in terms of the industry mix effect are South Auckland, North Waikato, Nelson/Tasman, Rural Canterbury and Rural Otago. These are the regions which have had relatively rapid employment growth, but are not specialising in industries that are growing more than the national average. Another interesting grouping is that of Hutt Valley and Wellington City, which are regions which specialise in industries that are growing more than the national average (public and private services) but with relatively slow employment growth overall. Again given the caveat of employment being recorded at the place of residence rather than the workplace this reflects more limited employment growth in public sector employment in Wellington city rather than the decline in manufacturing employment in the Hutt Valley.

It is useful to delve a little deeper into the grouping of regions by considering the competitive effect for each industry as calculated by equation (4) separately. Table 10 reports the average of $\left(g_{i j}^{\prime}-g_{i 0}^{\prime}\right)$ for each industry $i$ and region $j$ over the three intercensal periods. Clusters of regions have been identified in terms of these data by standard cluster analysis (e.g. Everitt, 1993). The methodology adopted is based on average between-group linkage with similarity defined by means of squared Euclidean distance. The maximum number of clusters was set at nine.

Table 9: Grouping of Regions Based on the Competitive and Industry Mix Effects

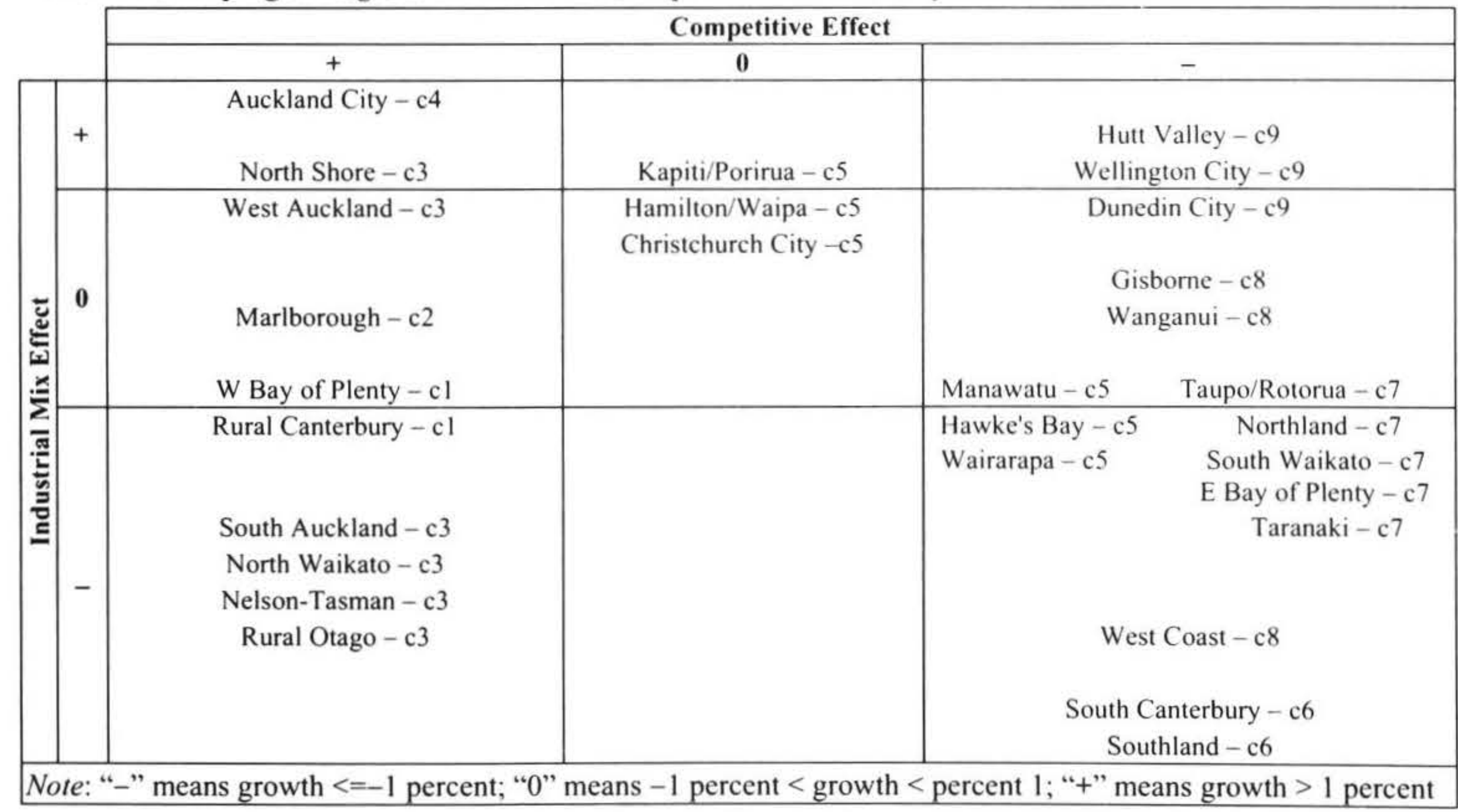


Table 10: The Difference Between Regional Sectoral Growth and National Sectoral Growth, 1986-2001 Average

\begin{tabular}{|c|c|c|c|c|c|c|c|}
\hline Region & $\begin{array}{l}\text { Business } \\
\text { and } \\
\text { Financial } \\
\text { Services }\end{array}$ & $\begin{array}{c}\text { Public } \\
\text { Services, } \\
\text { Social } \\
\text { Services, } \\
\text { Utilities }\end{array}$ & $\begin{array}{l}\text { Personal, } \\
\text { Household, } \\
\text { Restaurants } \\
\text { and Hotels }\end{array}$ & $\begin{array}{l}\text { Distribution } \\
\text { and Exchange } \\
\text { (Retail and } \\
\text { Whole-sale) }\end{array}$ & $\begin{array}{l}\text { Building } \\
\text { and } \\
\text { Con- } \\
\text { struction }\end{array}$ & $\begin{array}{l}\text { Manu- } \\
\text { facturing }\end{array}$ & Primary \\
\hline Northland & -3.8 & 0.3 & -5.8 & -2.0 & -9.2 & -0.9 & -2.1 \\
\hline North Shore & 1.8 & 5.5 & 2.5 & 3.8 & 7.4 & 3.0 & 0.3 \\
\hline West Auckland & 8.3 & 10.3 & 2.2 & 5.3 & 10.0 & 1.1 & 0.1 \\
\hline Auckland City & 8.2 & 4.4 & 0.4 & 2.0 & -2.9 & -6.3 & 14.5 \\
\hline South Auckland & 6.4 & 4.5 & 3.7 & 9.4 & 6.1 & -1.0 & 0.2 \\
\hline North Waikato & 13.1 & 1.2 & 5.9 & 8.2 & 6.1 & 5.0 & -6.3 \\
\hline Hamilton/Waipa & -5.0 & 1.3 & 1.0 & 0.9 & 0.2 & 4.3 & 3.5 \\
\hline South Waikato & -7.9 & -6.3 & -12.6 & -5.1 & -7.5 & -2.3 & -4.7 \\
\hline Western Bay of Plenty & 8.0 & 14.0 & 5.0 & 9.0 & 13.9 & 13.6 & 0.5 \\
\hline Eastern Bay of Plenty & -3.2 & 3.8 & -7.7 & -3.4 & -5.3 & -6.8 & -6.7 \\
\hline Taupo/Rotorua & -6.6 & -2.2 & -2.2 & -0.2 & -8.4 & 3.3 & -5.3 \\
\hline Gisborne & -19.9 & -6.4 & -11.2 & -8.3 & -8.6 & -9.2 & 1.5 \\
\hline Hawke's Bay & -8.3 & -1.7 & -4.4 & -3.4 & -2.2 & -0.4 & 4.4 \\
\hline Taranaki & -5.5 & -6.8 & -7.0 & -7.4 & -11.7 & 0.9 & -5.5 \\
\hline Wanganui & -16.5 & -11.3 & -10.0 & -10.7 & -15.7 & -1.1 & -1.8 \\
\hline Manawatu & -7.2 & -1.7 & -3.6 & -3.6 & -2.7 & -3.1 & 1.2 \\
\hline Kapiti/Porirua & 1.2 & 1.4 & 4.1 & -2.6 & 4.1 & -5.2 & 2.3 \\
\hline Hutt Valley & -5.6 & -6.3 & -5.0 & -6.4 & -0.3 & -10.2 & 15.7 \\
\hline Wellington City & -4.2 & -2.6 & 0.2 & -9.1 & -6.1 & -6.2 & 7.8 \\
\hline Wairarapa & -1.6 & -0.6 & -0.5 & -2.7 & 2.5 & -3.0 & 1.3 \\
\hline Nelson-Tasman & 4.7 & 0.2 & 5.4 & 5.3 & 5.6 & 7.6 & 4.2 \\
\hline Marlborough & 0.4 & -3.6 & 8.3 & -0.9 & 4.9 & 23.5 & 14.3 \\
\hline West Coast & -13.7 & -8.7 & 0.3 & -5.2 & -7.6 & -4.9 & -2.9 \\
\hline Christchurch City & 0.0 & -1.7 & 4.1 & 0.5 & 4.5 & 1.0 & 10.0 \\
\hline Rural Canterbury & 21.1 & 5.7 & 8.2 & 8.7 & 17.5 & 16.7 & 1.7 \\
\hline South Canterbury & -11.3 & -8.5 & -6.5 & -6.6 & -1.4 & 7.1 & 4.3 \\
\hline Dunedin City & -15.0 & -1.3 & 1.1 & -9.6 & -6.8 & -1.3 & 10.8 \\
\hline Rural Otago & 6.2 & -1.5 & 7.4 & 1.3 & -3.9 & 11.3 & 1.6 \\
\hline Southland & -15.4 & -8.8 & -9.6 & -8.4 & -0.2 & 2.6 & -0.2 \\
\hline
\end{tabular}

Table 11: Cluster Analysis Results

\begin{tabular}{|c|l|c|l|c|l|}
\hline Cluster & \multicolumn{1}{|c|}{ Regions } & Cluster & Regions & Cluster & \multicolumn{1}{c|}{ Regions } \\
\hline 1 & $\begin{array}{l}\text { Western Bay of Plenty; Rural } \\
\text { Canterbury }\end{array}$ & 4 & Auckland City & $\begin{array}{l}\text { Taupo/Rotorua; Northland; } \\
\text { Eastern Bay of Plenty; } \\
\text { South Waikato; Taranaki }\end{array}$ \\
\hline 2 & Marlborough & 5 & $\begin{array}{l}\text { Hamilton/Waipa; Christchurch } \\
\text { City; Kapiti/Porirua; } \\
\text { Wairarapa; Hawke's Bay; } \\
\text { Manawatu }\end{array}$ & 8 & $\begin{array}{l}\text { West Coast; Gisborne; } \\
\text { Wanganui }\end{array}$ \\
\hline 3 & $\begin{array}{l}\text { West Auckland; South } \\
\text { Auckland; North Shore; North } \\
\text { Waikato; Nelson-Tasman; }\end{array}$ & 6 & South Canterbury; Southland & 9 & $\begin{array}{l}\text { Dunedin City; Wellington } \\
\text { City; Hutt Valley }\end{array}$ \\
\hline
\end{tabular}

The clusters that resulted are shown in Table 11.

Given the selected methodology, the resulting clusters are in fact closely correlated with the ranking of the aggregate competitive effect, as given in Table 7. Thus, Western Bay of Plenty and Rural Canterbury are in one cluster due to having the highest competitive effect, whereas regions such as West Coast, Gisborne and Wanganui are a cluster of regions with very negative competitive effects.
The clustering is, however, also related to the industrymix effect. The clusters are also indicated in Table 9. This shows that the informal grouping based a cross-tabulation of positive, small or negative industry mix and competitive effects is consistent with the clustering based on a formal cluster analysis. The latter can be sensitive to the order of variables and the distance measure adopted, 
so that it is comforting to find that the resulting clusters do permit a straightforward interpretation.

The caveat here is that the analysis is done purely on the basis of classic shift-share analysis.

\section{Alternative Formulations}

As noted earlier there are a number of criticisms of classic shift share analysis. As a result of these criticisms a number of extensions of the classic model have been suggested in the literature (see for example EstebanMarquillas (1972), Keil (1992), Arcelus (1984), Berzeg (1984), Mulligan and Molin (2004) and others reviewed by Loveridge and Selting (1998)). These alternative formulations are considered in some detail in Poot et al. (forthcoming). The results of these are broadly in line with those achieved by the classical method.

Of particular interest is our finding in the working paper that regions that are successful in attracting additional migrants do generate further employment growth that is reflected in a subsequent competitive effect (i.e. is unrelated to the industry composition of the region).

\section{Conclusions}

In this paper we use classic shift-share analysis to identify some forces of New Zealand regional employment change over the 1986-2001 period, which includes a decade of drastic economic restructuring, liberalisation and reform. The introduction of a regional dimension greatly increases the complexity of any analysis of change. With 29 regions in the present analysis there is a thirty fold increase in the number of 'stories' to tell about the changes that have taken place in the regional labour markets. Shift-share analysis is just a simple technique to make such a description of change more manageable. This is further enhanced by cluster analysis. In terms of the forces of change, shift-share analysis shows that the national growth effect has been dominant in all regions. No region could escape from the massive national changes that took place since 1986 . Industry endowment also plays a certain role, but not a major one in terms of its contribution to regional employment growth. Nonetheless, we do find that no region has been going against the trend: where industry mix signalled a disadvantage, the industry-structure was modified in the 'right' direction to ameliorate this disadvantage. The analysis also confirms that most of the structural change took place during the first five years of the 1986-2001 period.

The dichotomisation between the metropolitan regions, and their satellite cities, on the one hand, and the declining peripheral and rural regions on the other that has been identified in earlier research is reinforced here. The clustering highlights the chasm that has developed in New Zealand between metropolitan and other servicesoriented regions vis-à-vis rural and peripheral regions. A decline in manufacturing and a growth in what Pool et al. (forthcoming) refer to as the quaternary sector (business and financial services, and the knowledge industries of the 'new' economy) have shaped employment outcomes that are confirmed by clusters of prosperity and disadvantage.

In this paper we have used the terminology of classic shift-share analysis. Accordingly we referred to the residual employment growth rate that resulted from controlling for national growth and regional sectoral composition as the competitive growth rate. This labelling attributes the presence of competitive forces to this residual, whereas - as noted earlier in this paper there may be many other factors operating simultaneously at the micro level. These include regional differences and changes in labour force participation, migration and the demographic structure of the local population, new investment and labour productivity. To disentangle the contribution of such factors to the residual of shift-share analysis requires the formulation of a well-specified econometric model of regional employment change, ideally at the level of local labour market areas. Using pooled 1986-2001 census and other data, such a model may complement time-series approaches (such as Choy et al. 2002) and will be the aim of future research.

Finally, spatial spillovers are largely ignored in classic shift-share analysis. The importance of such spillovers is clear from the tables provided in this paper, which show that regional outcomes in any particular region are often linked to those of surrounding regions. While formal spatial econometric work in a panel setting is feasible, it would require a much greater regional disaggregation to be meaningful. This also offers an avenue for further research.

\section{Note}

1. This research is part of the New Demographic Directions Programme (NDDP) at the Population Studies Centre of the University of Waikato and has been funded by the Foundation for Research, Science and Technology. Corresponding author: Jacques Poot, jpoot@waikato.ac.nz

\section{References}

Arcelus, F.J. (1984) "An Extension of Shift-Share Analysis", Growth and Change, 15, 3-8.

Ashby, L.D. (1968) "The Shift and Share Analysis: A Reply”, Southern Economic Journal, 34, 423-25.

Berzeg, K. (1984) "A Note on Statistical Approaches to Shift-Share Analysis", Journal of Regional Science, 24, 277-285.

Bishop, K.C. and C.E. Simpson (1972) "Components of Change Analysis: Problems of Alternative Approaches to Industrial Structure", Regional Studies, 6, 59-68.

Butcher, G.V. (1985) Regional Income Output and Employment Multipliers: Their Uses and Estimates of Them, Wellington: Economics Division, Ministry of Agriculture and Fisheries. 
Choy, W.K., Maré, D.C. and Mawson, P. (2002) "Modelling Regional Labour Market Adjustment in New Zealand". New Zealand Treasury Working Paper 02/01, Wellington: The Treasury.

Dinc, M, Haynes, K.E. and Qiangsheng, L. (1998) “A Comparative Evaluation of Shift-Share Models and Their Extensions", Australian Journal of Regional Studies, 4, 275-302.

Dunn, E.S. Jr. (1960) "A Statistical and Analytical Technique for Regional Analysis", Papers and Proceedings of the Regional Science Association. 6, 98-112.

Esteban-Marquillas, J.M. (1972) "A Reinterpretation of Shift-Share Analysis", Regional and Urban Economics, 2, 249-255.

Evans, L.T., Grimes, A. and Wilkinson, W., with Teece, D. (1996) "Economic Reform in New Zealand 1984-95: The Pursuit of Efficiency", Journal of Economic Literature, 34, 1856-1902.

Everitt, B. (1993) Cluster Analysis (3rd edition). London: Arnold.

Hall, V.B. and McDermott, C. (2004) Regional Business Cycles in New Zealand: Do They Exist? What Might Drive Them?. Wellington: School of Economics and Finance, Victoria University of Wellington.

Haynes, K.E., and Dinc, M. (1997) "Productivity Change in Manufacturing Regions: A Multifactor/Shift-Share Approach", Growth and Change, 28, 201-221.

Karagedikli, Ö., Maré, D. and Poot, J. (2000) "Disparities and Despair: Changes in Regional Income Distributions in New Zealand 1981-1996", Australasian Journal of Regional Studies, 6, 323347

Karagedikli, Ö., Maré, D. and Poot, J. (2002) "Changes in New Zealand Regional Income Distributions 1981-1996". In: E.T. Gomez and R. Stephens (eds) The State, Economic Development and Ethnic Co-existence in Malaysia and New Zealand. Center for Economic Development and Ethnic Relations, University of Malaya, Kuala Lumpur.

Keil, S.R. (1992) "On the Value of Homotheticity in the Shift-Share Framework", Growth and Change, 23, 469-493.

Killerby, P., Macpherson, R. and Smith, J. (2004) "Regional Partnerships and Jumbled Jurisdictions:
The Changing Face of Regional Economic Development in New Zealand, Sustaining Regions, 4, 4-15.

Knudsen, D.C. (2000) "Shift-share analysis: further examination of models for the description of economic change", Socio-Economic Planning Sciences, 34, 177-198.

Loveridge, S. and Selting, A.C. (1998) "A Review and Comparison of Shift-Share Identities", International Regional Science Review, 21, 37-58.

McDonald, T.K. (1969) Regional Development in New Zealand. Wellington: New Zealand Institute of Economic Research.

Mulligan, G.F. and Molin, A. (2004) "Estimating Population Change with a Two-Category ShiftShare Model", Annals of Regional Science, 38, 113-130.

Munro, J.M. and Schachter, G. (2000) Regional Industrial Specialization and Patterns of Structural Unemployment in the European Union. In: $\mathrm{H}$. Kohno, P. Nijkamp and J. Poot Regional Cohesion and Competition in the Age of Globalization, Cheltenham UK and Northampton MA USA: Edward Elgar.

Patterson, M.G. (1989) "Regional Employment in New Zealand 1981-86: Shift-Share versus Regression Analysis", New Zealand Geographer, 45, 26-35.

Perroux, F. (1950) "Economic Space, Theory and Applications", Quarterly Journal of Economics, 64, 89-104.

Pool, I., Baxendine, S., Bedford, R., Cochrane, W., Lidgard, J. and Lindop, J. (forthcoming) Developing Underdevelopment and Geographical Disparities: A Social Demography of New Zealand Regions. Hamilton: Population Studies Centre.

Poot, J. (2002) The Impact of Globalisation on Regional Labour Markets. In: Y. Higano, P. Nijkamp, J. Poot and K. Van Wyk (eds) The Region in the New Economy, Ashgate, Aldershot UK.

Poot, J., Baxendine, S., Pool, I and Cochrane, W., (forthcoming) Forces of Regional Economic Change: A Dynamic Shift-Share Analysis of New Zealand Regions 1986-2001, Hamilton: Population Studies Centre.

Statistics New Zealand (2003) Regional Input-Output Study, Wellington: Statistics New Zealand. 